\title{
DYSFUNCTIONS OF THE MOTIVATION SYSTEM FROM THE PERSPECTIVE OF EMPLOYEES OF THE LOCAL GOVERNMENT UNITS
}

\author{
Marek Ćwiklicki*, Anna Urbaniak**
}

\begin{abstract}
Background. The lack of extensive research with regard to personnel management of local government units (LGUs) prompted the authors to undertake analyses, the purpose of which was to give the voice to the respondents, according to the assumptions of the constructivist paradigm.
\end{abstract}

Research aims. The purpose of the study was to identify the main management problems from the perspective of LGU employees.

Methodology. The basis of the conducted analyses were the essays of LGU employees concerning the management problems they noticed at their workplaces. The qualitative methodology has been used (the content analysis combined with the elements of grounded theory).

Key findings. The motivation system model applied in LGUs was reconstructed, from the perspective of the respondents, and factors were distinguished, which - in the opinion of the employees - cause the functioning system as not motivating in the intended scope. On the basis of a comparison of the existing legal regulations and the respondents' narratives, a list of recommendations was prepared, with regard to design and functioning of the employee motivation systems at LGUs.

Key words: dysfunctions, motivating, local government, quality surveys

\section{INTRODUCTION}

The premise for undertaking the research was the observation of the authors of the report on the condition of local self-government in Poland, stating that "it is difficult to assess in a comprehensive manner

\footnotetext{
* Cracow University of Economics. E-mail: marek.cwiklicki@uek.krakow.pl

** Cracow University of Economics. E-mail: anna.urbaniak@uek.krakow.pl
} 
the approach of LGUs [local government units] to human resources management" (Bober et al., 2013, p. 40). It was justified by the lack of extensive research in this respect. The authors referred only to the benchmarking base created for the purposes of the previous edition of the Institutional Development Plan from 2010 (Baza benchmarkingowa PRI 2010, 2010), in which in the area of "Human Resources Management", four criteria were distinguished: personnel planning, recruitment, and selection; motivation, assessment, and promotion; professional development and ethics. An important element, from the point of view of this article, is the area concerning motivation, assessment and promotion of employees, ranked by the offices themselves at the second level on the 5 -grade scale. This suggests the need to undertake further research, contributing to filling the gap in this field. Results of the analysis of the collected data to a certain extent correspond to and supplement the research conducted by W. Szumowski on motivation and satisfaction at work in local administration offices (Szumowski, 2014).

An additional circumstance to investigate the given problem is the observation that local government public workers are harder to motivate (Lavigna, 2014). The literature about the motivation system in public administration is vast (cf. Cichocki, \& Moser, 2016; Lenik, 2009; Perry, 1997; Poister, \& Streib 1999; Wright, 2001; Vandenabeele, 2007), and therefore the description of the motivation systems and explanation how they are created in LGU was purposely omitted as this paper concentrates on practice and employees' narratives with focuses on specific aspects of the dysfunction of motivation.

The goal of this article is to find answers to the following question: what problems do the LGUs employees notice in their organisations and how they define them. The conducted analyses indicated that, from the perspective of the respondents, the most important problem was the presence of dysfunctions in the motivation system. That is why the authors decided to focus on this issue in the presented article.

\section{RESEARCH METHODOLOGY}

The approach used in this study fits the trend of quality surveys and incorporates both the quantitative elements, typical of the content analysis, as well as elements used in the grounded theory approach. 
The content analysis, as one of the methods of secondary data analysis, may be treated as counting up the instances of certain motifs or words, or "as the understanding of the categories used by participants in the social life and learning how they are being used in specific activities" (Silverman, 2011, p. 150). This article, assuming the second approach, is aimed at finding answers to the following question: What problems do the employees of local government units notice in their organisations and how do they define them?

The empirical material used in the analysis were essays of students in postgraduate study programs "Management in Public Administration", held by the Małopolska School of Public Administration of the Cracow University of Economics, who were asked to write a statement answering the following question: "What, if any, management problems do you notice in the organisation that you represent?". The essays were anonymous; the students were only requested to indicate the type and size of the organisation employing them. The analysis covered 45 essays written between 2014 and 2016, by representatives of communal and municipal units. The essays were not limited by any specific form, and the respondents were free to choose both: the method of description, as well as the analysed phenomena. Therefore, essays were deemed to be a sufficient representation of the phenomena observed by the respondents with regard to management problems in their institutions. Due to the great freedom in answering the questions, the respondents made their own decision on whether they were going to describe a single problem or several problems. It was decided that such a freedom guarantees the researchers access to data that the respondents themselves regarded as important and worth presenting. Thanks to that, it was possible to select issues to which the respondents devoted the majority of attention in their essays.

The collected material was then coded by two independent coders, who achieved a high degree of encoding consistency. All analyses were conducted with the use of RQDA, a specialist software for qualitative data analysis, which not only significantly accelerated the process, but also ensured transparency and accuracy of the conducted research. In order to increase the reliability and accuracy of the analysis, the process involved not only specialist software, but also triangulation of researchers. As a result, it was possible to go beyond the individual level of interpretation and conduct in-depth analysis of the examined fragment of reality. 
Open coding was used in the study. This enabled analysis of data from the respondents' narratives, the reference point for which consisted of these narratives rather than the previously developed theoretical concepts (Holton, 2007). This allowed for reconstructing a list of issues, which the respondents themselves defined with regard to the problems at their workplaces. After a repeated analysis of the encoded statements, axial coding was used, and then the key category was distinguished, which allowed for ultimately arranging the developed system of codes and their interrelations (Corbin, \& Strauss, 2008; Glaser, 1998; Holton, 2007). This category was 'motivating' therefore the article is devoted to it. In the article, next to quotations, square brackets are used in order to identify the essay and the year of its creation.

\section{ANALYSIS OF THE RESEARCH RESULTS}

It seems reasonable to place the subjective narrations of LGU employees concerning the motivation system in a more objective context, i.e., of legal regulations currently in force in Poland. For this reason, before presenting the relevant analyses of the respondents' statements, the article presents the basic legislation regulating the area of local administration employee motivation.

\section{The LGU employee motivation system in the light of regulations contained in the binding legal acts}

The basic legal act describing the issues belonging to local administration employee motivation in Poland is the Act on Local Administration Employees (ALAE) of 21 November 2008 (Journal of Laws of 2008, No. 223, item 1458) - hereinafter referred to as ALAE. Its provisions include fragments of issues, which - according to the subject literature - constitute the foundations of the organisation's motivation system.

The key element for the local administration employee remuneration system in Poland are the remuneration regulations, which - according to Article 39 of ALAE - determine the qualification requirements of local administration employees and the detailed conditions of remuneration, including the maximum level of the basic remuneration. Article 38 precisely indicates the anniversary bonus amount as a percent of the monthly remuneration, dependent upon the years of work seniority. 
Point 2 of Article 39 allows for determining the conditions of granting and the conditions and method of paying bonuses and rewards other than the anniversary bonus, as well as special and position allowances.

According to Article 27 of ALAE, a local government employee is subject to periodic performance appraisal conducted by their direct superior, no less frequently than once every 2 years and no more often than once every 6 months. Point 9 of this Article states that obtaining a negative performance appraisal twice results in termination of the contract for employment. The appraisal method is determined by way of the regulation of the entity's manager.

The Act emphasises that employees "participate in various forms of improving knowledge and professional qualifications" (Article 29 point 1), and that the financial plans "provide funds for improving knowledge and professional qualifications" (Article 29 point 2).

Separate place is given to the company's social benefits fund (CSBF), which - pursuant to the Act - is obligatorily created in budgetary units and in budgetary local administration institutions. It is used to fund certain activities (e.g. self-arranged holidays, integration trips, etc.).

The elements presented above constitute the basis for financial motivations and - through CSBF - non-financial. The indicated legal acts set out a very general framework, within which operationalisation was left to LGUs. On this basis, we may formulate a conclusion that each LGU has parts corresponding the above regulations, but established separately from one another, not formed as one coherent whole. This will affect the perception of motivation in LGUs as a system. Due to the fact that the goal of the article is not to evaluate the formal documentation related to motivating LGU employees, nor its comparison with the respondents' opinions, the authors decided to merely synthetically describe the legal status in Poland.

\section{The LGU employee motivation system in the light of the employees' narratives}

The analysis of the LGU employees' narratives determined "motivating" as the key category, enabling ordering and understanding of the relations among the previously created codes. The main category, on the basis of which the description below has been prepared, is thus the motivation system and the accompanying dysfunctions and suggestions concerning its proper shape. The key issue mentioned by the 
respondents is the lack of a coherent motivation system in the LGUs. The respondents are not familiar with its details, or think that this system is unclear and poorly developed. Solutions in this respect are not regulated in written form.

By conducting the synthesis of the collected research material and including in the interpretation of the results of the respondents perspective, a model of the motivation system in LGUs was prepared (see Figure 1). It is of a causal nature and shows the linkages between the main elements of the motivation system.

Selection of the motivational tools takes place on the basis of the existing determinants, typical of a particular organisation, which include: compliance with the employee's needs, available funds, impact of the social control on management of the available means. The selected tools are used by the managers. The employees, in response to those tools, but also to non-systematic factors, undertake particular actions. Later, they evaluate the involved effort in comparison to the obtained result and the potential awards. The result is the nature of the impact that may generate desirable effects, such as: professional development of employees, achievement of optimum results and attachment to the workplace and co-workers, or undesirable ones: apathy, fluctuation, and low level professionalism of the officials. The model also takes into account the need for improvement of the motivation system with regard to selection of tools and their use.

The main determinant of motivating the officials involves a limited financial resource. Interestingly, the respondents emphasised that, despite the specific nature of local government units - as non-profit organisations - these organisations are not deprived of the possibility of effectively motivating their employees, although in a smaller extent than business companies.

An equally important factor, determining both the manner of motivating, as well as the selection of motivational tools by the LGUs managers, is the strong influence of the social control. It includes both the impact of the opinion of the closest environment (the managers of other departments within one unit), as well as the external environment of the organisation and the legal regulations concerning public finance discipline, which is depicted in the statement: "The Head of the Commune/the Mayor is afraid to use the financial award system, because it exposes him to criticism from councillors and the environment" [4/2013]. 


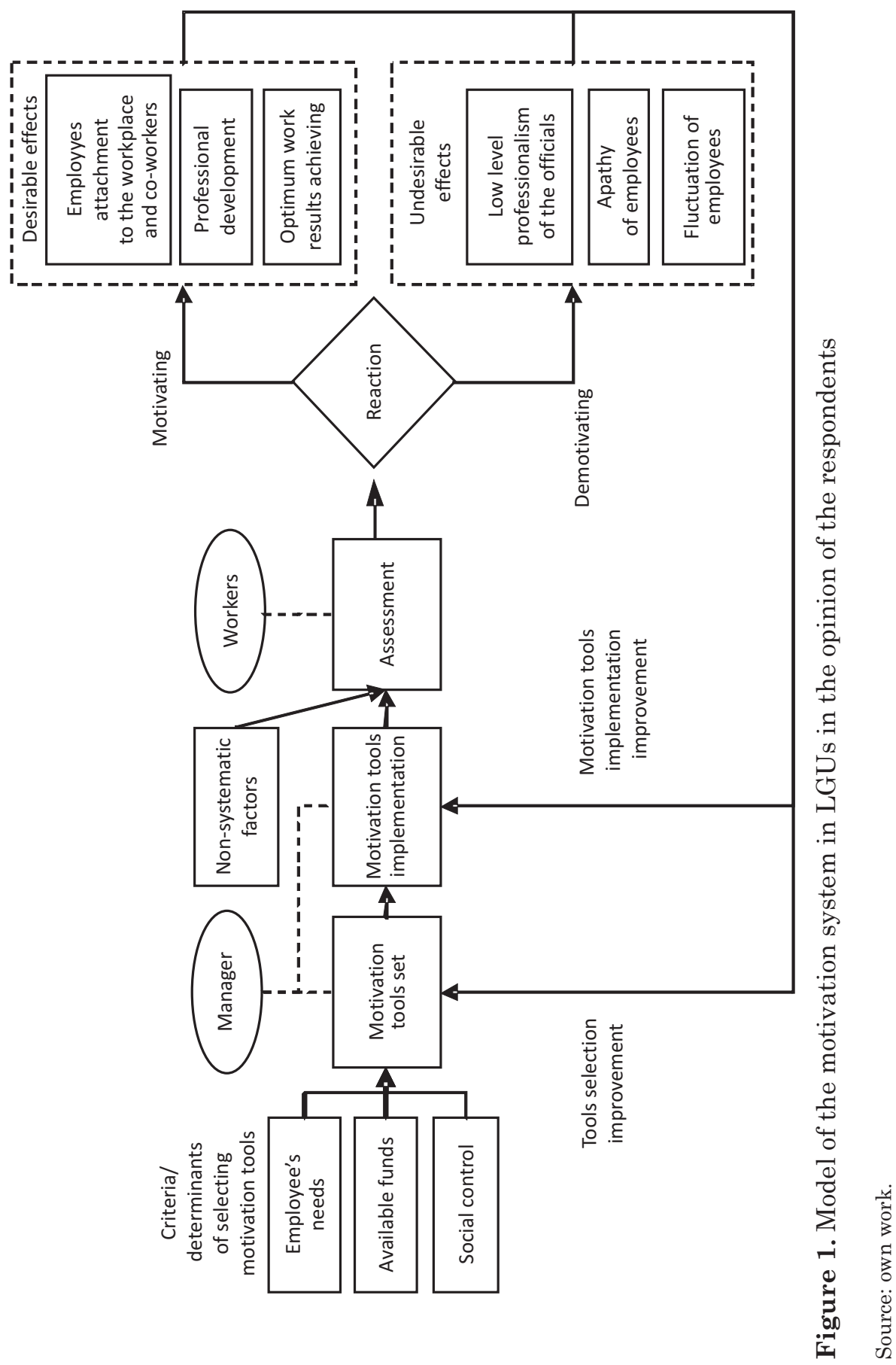


From the perspective of the respondents, motivation is the most important, but also the most problematic function of human resources management in the office. It is believed to be difficult and complex. In the opinion of the respondents the person responsible for its execution is, above all, the unit's manager.

According to the respondents the main challenge in its implementation is the way to "motivate the employees while having limited possibilities, so that they would achieve professional satisfaction, while simultaneously increasing work efficiency" [2/2013]. The respondents noticed the benefits of proper motivation from both perspectives of the employer, as well as an employee. For the former, this means, among others, achieving optimum work performance, and thereby the employee: "gains greater experience, develops, increases his/her qualifications, becoming "in high demand» on the labour market. It often allows him/her to transfer to another organisation, where - in new conditions and with renewed motivation - he/she will further develop his/her "career»" [2/2013].

As it has been already mentioned, in the opinion of the respondents, the unit's manager is responsible for motivation. However, the respondents note the lack of motivational actions undertaken by the superiors in situations, when they should have responded: "The manager does not reward, but also does not punish in situations that would require such actions" [2/2014].

A consequence of the lack of motivation is the lack of involvement of the officials in their work. In such situations, they assume passive attitudes. The long-term effect is a reduction in efficiency, due to the lack of highly qualified staff: "If the commune cannot afford a decent monthly remuneration, or bonuses for its employees, the number of specialists and qualified workers consequently quits, which is reflected in the quality of work performed in the office" [2/2016].

The surveyed are convinced of the need to improve the motivation methods. It is believed that several methods should be used at the same time, selected according to the needs of the employees. Therefore, the first step should involve selection of the motivational tools. The main criterion in such selection is considered to be a lack of risk of exceeding the public finance discipline.

The statements include examples of failure to adjust the tools to the particular situation of the employee: "The employer "threatens" with 
reprimands, without considering heavy workloads of the employees" [4/2015].

\section{Characteristics of the main motivational tools and reasons for their ineffectiveness}

The respondents expressed their views on selected motivational tools in fair detail. The next section of the text presents their opinions on particular tools, which in their perspective do not fulfil their motivational role. The motivational instruments listed by the respondents can be arranged in accordance with the division adopted in Table 1. It should be emphasised that the set of these tools is not complete - full classifications of wage and non-wage motivation tools can be found in publications available in Poland (e.g. Juchnowicz, 2012; Kopertyńska (n.d.); Lenik, 2012; Pocztowski, 2003). This section of the study will present in detail those aspects, which appeared in the majority of the respondents' statements.

Table 1. Types of motivational instruments mentioned by the respondents

\begin{tabular}{|l|l|}
\hline \multicolumn{2}{|c|}{ Motivational instruments } \\
\hline \multicolumn{1}{|c|}{ Financial } & \multicolumn{1}{c|}{ Non-financial } \\
\hline - Basic salary & - Promotions and professional career \\
- Wage rises & - Training at the employer's cost \\
- Monetary awards & - Additional old-age pension and health insurance \\
- Bonuses & - Integration trips \\
- Job seniority allowances & - Material benefits \\
- Annual benefit & - Participation in management \\
& - Superior's appreciation \\
\hline
\end{tabular}

Source: own work.

It should be reminded that the research material collected by the authors includes only those tools, for which the respondents stated a loss of their motivational functions and/or irregularities in their application. The dysfunctions indicated by the respondents are presented in Table 2. 
Table 2. Motivating factors not fulfilling their functions, along with indication of moderators affecting disruption of the motivational function

\begin{tabular}{|c|c|c|}
\hline $\begin{array}{l}\text { Assumedly } \\
\text { motivating } \\
\text { factor }\end{array}$ & $\begin{array}{l}\text { Cause of inef- } \\
\text { fectiveness }\end{array}$ & Selected quotations from the survey \\
\hline $\begin{array}{l}\text { Financial } \\
\text { awards }\end{array}$ & $\begin{array}{l}\text { Lack of clear } \\
\text { criteria for } \\
\text { granting } \\
\text { awards }\end{array}$ & $\begin{array}{l}\text { "Another defect involves, in my opinion, non-trans- } \\
\text { parent mechanisms of rewarding employees, which } \\
\text { affects lack of motivation to work" [1/2014] } \\
\text { "Lack of a clear motivation system (also financial). } \\
\text { The employees are awarded at the discretion of the } \\
\text { manager, rather than for the actual contribution and } \\
\text { commitment" [2/2014] } \\
\text { "(..) non-transparency in their [awards] granting } \\
\text { and the use of different criteria towards particular } \\
\text { employees and departments, is the additional cause of } \\
\text { an unhealthy atmosphere" [4/2013] } \\
\text { "Only awards are granted (once, twice a year). They } \\
\text { are not dependent upon actual commitment or work } \\
\text { results, nor upon the result of the employee appraisal. } \\
\text { The criteria taken into account when determining } \\
\text { their amounts are a great mystery" [13/2014] } \\
\text { "Usually once a year, awards are granted to most } \\
\text { employees, but obtaining the award and its level are by } \\
\text { any means dependent upon the employees' efficiency. } \\
\text { The County Governor grants the awards (if any) ac- } \\
\text { cording to a repeated pattern - one award per year for } \\
\text { most employees, and the amount depends on the po- } \\
\text { sition held. This does not favourably affect motivation } \\
\text { and creativity at work in the County Office" [2/2015] }\end{array}$ \\
\hline & $\begin{array}{l}\text { Lack of clear } \\
\text { criteria of } \\
\text { determining } \\
\text { the amount of } \\
\text { the awards }\end{array}$ & $\begin{array}{l}\text { "The awards are granted to all employees, regardless } \\
\text { of their contribution and involvement in work. The } \\
\text { difference is only in the amount of the award, which } \\
\text { is a certain percentage of the amount of remuneration } \\
\text { that the employee receives. A high salary equals a } \\
\text { high award. This way of rewarding the employees } \\
\text { does not motivate them it in any way, because they } \\
\text { know that if they receive an award, everyone does } \\
\text { and it does not depend on their own accomplish- } \\
\text { ments" [3/2014] } \\
\text { "The system for granting annual awards is demotivat- } \\
\text { ing, as their amount should depend on contribution } \\
\text { and effort of a given employee throughout the whole } \\
\text { year, and not only on his involvement displayed just } \\
\text { for show before the end of the year. Such situations } \\
\text { recur every year. People, who fail to perform their } \\
\text { official duties or perform them in a way substantially } \\
\text { different from the adopted standards are not held } \\
\text { responsible in any way, which the other diligent em- } \\
\text { ployees hold against the management" [5/2014] } \\
\text { "There is no reflection in the received annual award, } \\
\text { since each employee receives the same award } \\
\text { amount" [6/2016] } \\
\text { "Here, the awards are granted to everyone equally, } \\
\text { or because it's already been a long time since a given } \\
\text { employee received any award" [7/2016] }\end{array}$ \\
\hline
\end{tabular}


Table 2. cd.

\begin{tabular}{|c|c|c|}
\hline $\begin{array}{c}\text { Assumedly } \\
\text { motivating } \\
\text { factor }\end{array}$ & $\begin{array}{l}\text { Cause of inef- } \\
\text { fectiveness }\end{array}$ & Selected quotations from the survey \\
\hline & $\begin{array}{l}\text { Limited } \\
\text { amount of } \\
\text { funds allocat- } \\
\text { ed for awards }\end{array}$ & $\begin{array}{l}\text { "The main problems related to motivating LGU } \\
\text { employees are caused, first of all, by the financial } \\
\text { situation" [2/2013] } \\
\text { "The issue of motivating public administration em- } \\
\text { ployees is an extremely difficult task, for instance due } \\
\text { to limited funds (it is public money that always has to } \\
\text { be accounted for) (...). In fact, this low rise, instead of } \\
\text { motivating, discourages LGU employees from work- } \\
\text { ing" [4/2014] }\end{array}$ \\
\hline & $\begin{array}{l}\text { Low frequen- } \\
\text { cy of use by } \\
\text { the superiors }\end{array}$ & $\begin{array}{l}\text { "Most inhabitants of the Commune make thorough } \\
\text { observations and evaluations of the spent public } \\
\text { funds, which effectively discourages the organisation's } \\
\text { manager from spending public funds to improve the } \\
\text { well-being of office workers" [2/2013] }\end{array}$ \\
\hline $\begin{array}{l}\text { Employee } \\
\text { appraisal }\end{array}$ & $\begin{array}{l}\text { No impact } \\
\text { of employee } \\
\text { appraisal } \\
\text { on employee } \\
\text { remuneration }\end{array}$ & $\begin{array}{l}\text { "In reality, the [employee] appraisal unfortunately } \\
\text { isn't reflected in awards and promotions, so it's not a } \\
\text { method of motivating employees" [1/2013] } \\
\text { "The appraisal is conducted on the basis of once } \\
\text { agreed criteria, and furthermore, its results are rep- } \\
\text { licated each year. In addition, the result of this ap- } \\
\text { praisal has no measurable effects. It's merely a piece } \\
\text { of paper, which has to be included in the employee's } \\
\text { personal files" [13/2014] }\end{array}$ \\
\hline \multirow[b]{3}{*}{ Training } & $\begin{array}{l}\text { Lack of } \\
\text { free places } \\
\text { relative to the } \\
\text { demand }\end{array}$ & $\begin{array}{l}\text { "The described Office sometimes sends employees to } \\
\text { various types of training and courses. This is a good } \\
\text { practice, however, according to the people working } \\
\text { there, the number of vacant places in such courses is } \\
\text { greatly smaller than the demand" [10/2016] }\end{array}$ \\
\hline & $\begin{array}{l}\text { Inadequate to } \\
\text { the needs of } \\
\text { employees }\end{array}$ & $\begin{array}{l}\text { "The weakness of the system of training and qualifica- } \\
\text { tion improvement, since the management staff often } \\
\text { set in advance a training, which is inadequate to the } \\
\text { actual needs of the officials, and a diagnosis of the } \\
\text { training needs is rarely conducted" [9/2016] }\end{array}$ \\
\hline & $\begin{array}{l}\text { Training is } \\
\text { selected not } \\
\text { for their sub- } \\
\text { ject matter } \\
\text { and quality, } \\
\text { but for its } \\
\text { price }\end{array}$ & $\begin{array}{l}\text { "Training and courses are easily accessible, however, } \\
\text { their level may vary" [9/2013] } \\
\text { "A training plan is created, determining the demand } \\
\text { for training. However, when making decisions } \\
\text { concerning selection of a training, the main decisive } \\
\text { factor is the cost of such training, and its quality is of } \\
\text { secondary concern" [2/2015] } \\
\text { "If an employee is sent to some training or course, it } \\
\text { is a training or course necessary for work at his or her } \\
\text { position, and obviously the cheapest one" [11/2015] } \\
\text { "There are no internal regulations with regard to } \\
\text { staff recruitment and the system of training and } \\
\text { professional improvement; decisions on participation } \\
\text { in a given training are taken on a current basis, usu- } \\
\text { ally on the basis of an offer submitted to the office" } \\
\text { [6/2016] }\end{array}$ \\
\hline
\end{tabular}


Table 2. cd.

\begin{tabular}{|c|c|c|}
\hline $\begin{array}{l}\text { Assumedly } \\
\text { motivating } \\
\text { factor }\end{array}$ & $\begin{array}{l}\text { Cause of inef- } \\
\text { fectiveness }\end{array}$ & Selected quotations from the survey \\
\hline $\begin{array}{l}\text { Management's } \\
\text { praise }\end{array}$ & $\begin{array}{l}\text { Treated as } \\
\text { encourage- } \\
\text { ment to com- } \\
\text { pete rather } \\
\text { than } \\
\text { a motivation }\end{array}$ & $\begin{array}{l}\text { "(..) groups have formed in the office departments, } \\
\text { which are favoured by particular managers. (...) } \\
\text { Often the Managers praise the so-called «their } \\
\text { people», which results in tensions between particular } \\
\text { employees of a given department and demotivates } \\
\text { other people, who have to measure up to those } \\
\text { «better» than themselves. Such people are relieved } \\
\text { of their duties, and others, who already have too } \\
\text { much work, are put under even more pressure. Such } \\
\text { methods lead to a decrease in work efficiency. After } \\
\text { all, if this other guy can do it, why do I have to work } \\
\text { more?" [5/2014] }\end{array}$ \\
\hline
\end{tabular}

Source: own work.

The data presented in Table 2 expressly indicate the role of individual interpretations of LGU employees in the motivation system. That is why, when establishing the motivation systems, the LGUs should take into account not only the intentions of their creators, but also the possible interpretations of the recipients. A number of factors, assumedly motivating, may not actually fulfil their motivational functions and may lead to conflicts between the superiors and the employees, and to frustration for both sides.

\section{DISCUSSION}

In the conducted research, it has been noticed that factors, which were designed as motivating, in fact discourage the employees. Therefore the motivation systems described in the literature (cf. Kopertyńska, 2009) would not function properly in the LGU where the respondents work. It results from the fact that the impact of motivating factors depends on their interpretation by the employees. It also means that research results from previous studies (Michna, Grygiel, \& Grygiel 2015; Szumowski, 2014) would not correspond fully to the findings from the presented research.

The literature on the subject notes that a given incentive may lose the award function, if it appears too often and the rewarded individuals get used to it. In such a situation, it is treated as anticipated rather 
than extraordinary, and loses its initial function (Homans, 2005). This mechanism can be observed fully in the case of employee awards, as well as the so-called "thirteens" (additional remuneration of employees of the public sector). LGU employees do not treat them as an award especially due to the fact that they are predictable and the employees are used to them.

However, treating them as motivational or demotivational factors is not only affected by subjective interpretation of certain activities and stimuli. Equally great significance is attributed to distortions in the functioning of the motivation systems, associated for example with improper or incorrect application of a given motivation tool or failure to adapt it to the actual needs of the employees. This observation supports the revised public-sector model of work motivation proposed by Wright (2001, p. 577) which shows relations "work context $\rightarrow$ job attitudes $\rightarrow$ work motivation".

To substantiate the above application, we may use Herzberg's two-factor theory and the division into hygiene and motivation factors adopted therein (Herzberg, 1968/2003). According to this theory, proper functioning of motivation factors is possible after ensuring proper hygiene factors. Otherwise, employees are dissatisfied with their work.

\section{CONCLUSION}

The conducted research allows for formulating recommendations and conclusions with regard to the theory, methodology, and practice. Theoretical conclusions apply to suitability of classification of motivation factors in the perspective of F. Herzberg. The motivation theories, based on the content of the work and on the expectations are clearly represented in the model of the motivation system according to the respondents.

Methodical and empirical recommendations include adoption of detailed guidelines in the research, resulting from the two-factor theory, as well as instructions (guidelines), allowing for development and support of the functioning of the motivation system, positively assessed by its recipients, namely by the officials. This conclusion results from the observation of the demotivating impact of factors commonly regarded as motivators. 
Guidelines for designing the motivation system include:

- The employees' needs, also regarding expectations towards professional development, should be diagnosed.

- The motivation system should have a written form and it should be communicated to all employees on a regular basis (e.g. annually) which increases transparency of the rules for granting awards to administration staff. This is also a suggestion resulting from Szumowski's research (2014).

- Selection of the motivational tools should be carried out in terms of their compatibility with the needs and financial possibilities of the organisation.

- Diversity of the basic remuneration should be ensured.

- Several motivational tools should be used at once, diverse in terms of type (wage and non-wage), frequency of use (monthly, quarterly, semi-annually, and annually), and their compatibility with the employee's needs.

- The granting criteria and the amount of awards should be clearly defined and communicated to the officials.

- Periodic appraisal should take account of the motivation element.

- Trainings should support professional development of the employee, in accordance with the identified competence development needs, and thus their selection should not be based on the price, but on the subject matter.

- A training plan should be prepared for each employee, and the terms of participation in this training should be expressly stated. The training providers (trainers) should be evaluated by the training participants.

Guidelines regarding the functioning of the motivation system can be formulated as follows:

- The impact of non-system factors, which may reduce the effectiveness of the applied motivation factors, should be eliminated or minimised.

- Information should be gathered, for the purposes of improvement of the applied tools, the correctness of the selection of which should be verified. The authors suggest undertaking improvement actions once a year, taking account of the date of conducting the periodical appraisal of local administration employees. 
It should also be pointed out that the presented results are not representative, since the described problems are described by the LGU employees who at the same time attend postgraduate study programs held by the Małopolska School of Public Administration of the Cracow University of Economics. For this reason, the presented results should be treated as an exploratory analysis, the purpose of which was to identify how LGU employees define the problems present in their organisations and what significance they assign to them, rather than to create a complete list of the occurring problems. Despite this limitation, one can say that the novelty of this paper stems out from revealing the actual state of the motivational dysfunctions in Polish self-government administration.

To finalise, it is worth pointing out the limitations of the conducted analysis, including, above all, lack of direct contact with the studied people and working with secondary material, which prevented more in-depth study of certain research topics, which emerged in the course of the analysis. Among them, special attention should be paid to the issues concerning maternity and work at LGUs, as well as treating the employees different depending on their gender. It is definitely worth tackling these issues during further analyses. From the point of view of the practice of LGU management, an interesting direction of the future research involves a diagnosis of the reasons for the emergence of the indicated dysfunctions in motivating the employees of local government offices.

\section{REFERENCES}

Baza benchmarkingowa PRI 2010 (2010). http://baza.pri2010.msap.uek.krakow.pl/. Accessed August 12, 2016.

Bober, J., Hausner, J., Izdebski, H., Lachiewicz, W. et al. (2013). Narastajace dysfunkcje, zasadnicze dylematy, konieczne działania: raport o stanie samorzadności terytorialnej w Polsce. Kraków: Małopolska Szkoła Administracji Publicznej UEK, Fundacja Gospodarki i Administracji Publicznej.

Cichocki, H., \& Moser, K. (2016). Motywacja w systemie zarządzania zasobami ludzkimi administracji samorządowej. Kontrola Państwowa, 6, 122-136.

Corbin, J.M., \& Strauss, A.L. (2008). Basics of Qualitative Research: Techniques and Procedures for Developing Grounded Theory (3rd ed.). Thousand Oaks: SAGE Publications, Inc. 
Glaser, B. (1998). Doing Grounded Theory: Issues and Discussions. Mill Valley: Sociology Press.

Herzberg, F. (1968/2003). One More Time: How do You Motivate Employees? Harvard Business Review (January).

Holton, J. (2007). The Coding Process and Its Challenges. In: A. Bryant, K. Charmaz (eds.), The SAGE Handbook of Grounded Theory (pp. 265-289). London: SAGE Publications Ltd.

Homans, G. (2005). Zachowanie społeczne - jego formy elementarne. In: P. Sztompka, M. Kucia (eds.), Socjologia: lektury. Kraków: Znak, 35-45.

Juchnowicz, M. (2012). Zaangażowanie pracowników: sposoby oceny i motywowania. Warszawa: PWE.

Kopertyńska, W. (n.d.). System motywacyjny w organizacji (II). Wiedzainfo.pl, http:// www.wiedzainfo.pl/wyklady/120/system_motywacyjny_w_organizacji_ii.html. Accessed August 12, 2016.

Kopertyńska, W. (2009). Motywowanie pracowników-teoria i praktyka. Warszawa: Placet.

Lavigna, R. (2014). Why Government Workers Are Harder to Motivate. Harvard Business Review, November 28, https://hbr.org/2014/11/why-government-workers-are-harder-to-motivate. Accessed September 24, 2017.

Lenik, P. (2012). Motywatory pozapłacowe czyli droga do nowej jakości pracowników: przedsiębiorstwa i administracja publiczna. Warszawa: Difin.

Lenik, P. (2009). Pozapłacowe systemy motywacyjne-adaptacja doświadczeń sektora przedsiębiorstw do warunków administracji samorzadowej, unpublished doctoral dissertation, Wydział Zarządzania i Komunikacji Społecznej, Uniwersytet Jagielloński, Kraków, Poland.

Michna, A., Grygiel, K., \& Grygiel, P. (2015). Rekrutacja oraz system motywacyjny pracowników jako element zarządzania zasobami ludzkimi w wybranej jednostce administracji publicznej. Zeszyty Naukowe Politechniki Ślaskiej, Seria: Organizacja i Zarzadzanie, 78.

Perry, J.L. (1997). Antecedents of Public Service Motivation. Journal of Public Administration Research and Theory, 7, 2.

Pocztowski, A. (2003). Zarzadzanie zasobami ludzkimi. Strategie-procesy-metody. Warszawa: PWE.

Poister, T.H., \& Streib, G. (1999). Performance Measurement in Municipal Government: Assessing the State of the Practice. Public Administration Review, 59(4), 325-335.

Silverman, D. (2011). Interpreting Qualitative Data: A Guide to the Principles of Qualitative Research (4th ed.). Los Angeles: Sage. 
Szumowski, W. (2014). Motywowanie i satysfakcja z pracy w urzędach administracji samorządowej. Wyniki badań empirycznych. Nauki o Zarzqdzaniu, $3,67-76$.

Ustawa z dnia 21 listopada 2008 r. o pracownikach samorządowych, Dz.U. 2008, nr 223, poz. 1458 .

Ustawa z dnia 4 marca 1994 r. o zakładowym funduszu świadczeń socjalnych, Dz.U. 1994, nr 43, poz. 163.

Wright, B.E. (2001). Public-Sector Work Motivation: A Review of the Current Literature and a Revised Conceptual Model. Journal of Public Administration Research and Theory, 11(4), 559-586. 


\section{DYSFUNKCJE SYSTEMU MOTYWOWANIA Z PERSPEKTYWY PRACOWNIKÓW JEDNOSTEK SAMORZĄDU TERYTORIALNEGO}

\section{Abstrakt}

Tło badań. Brak kompleksowych badań w zakresie zarządzania kadrami jednostek samorządu terytorialnego (jst) skłonił autorów do podjęcia analiz, których celem było oddanie głosu samym badanym zgodnie z założeniami paradygmatu konstruktywistycznego.

Cele badań. Celem badań było zidentyfikowanie głównych problemów zarządzania z perspektywy pracowników jst.

Metodologia. Punktem wyjścia prowadzonych analiz były wypowiedzi pisemne pracowników jst dotyczące problemów zarządzania dostrzeganych przez nich w ich miejscach pracy. Zastosowano metodologię badań jakościowych (analiza treści i elementy teorii ugruntowanej).

Kluczowe wnioski. Odtworzono model systemu motywowania w jst z perspektywy badanych oraz wyodrębniono czynniki, które w opinii pracowników powodują że działający system nie motywuje w planowanym zakresie. Bazując na zestawieniu funkcjonujących regulacji prawnych z narracjami badanych, opracowano także listę rekomendacji w zakresie projektowania i funkcjonowania systemów motywowania pracowników w jst.

Słowa kluczowe: dysfunkcje, motywowanie, samorząd terytorialny, badania jakościowe 